\title{
Proposal of a framework for the selection of renewable energy technology systems in Africa
}

\author{
Marie-Louise Barry $^{1, *}$, Herman Steyn ${ }^{1}$, Alan Brent ${ }^{2}$ \\ ${ }^{1}$ University of Pretoria, Pretoria, South Africa \\ ${ }^{2}$ University of Stellenbosch, Stellenbosch, South Africa \\ *Corresponding author. Tel: +27 82901 7569, Fax: +27 12362 5307, E-mail: mlb@up.ac.za
}

\begin{abstract}
Energy is essential for economic development in Africa. The current electrification figures show that countries in sub-Saharan Africa are facing major challenges in reaching positive economic growth and supplying basic energy services to rural communities. Prior to this study a comprehensive framework of factors to select renewable energy technologies did not exist. The purpose of this research was to develop such a framework and to validate it by means of empirical analyses. A triangulation of methodologies including a literature analysis, focus group, Delphi study and case study was used to determine the framework of factors. This paper presents the final framework that includes both the thirteen criteria and measures to be used for the selection of renewable energy technologies in Africa. The paper further recommends the critical documentation that must be created for each competing technology.
\end{abstract}

Keywords: Renewable energy technology selection, Developing countries, Sustainable energy, Selection criteria, Framework of factors

\section{Introduction}

Energy is essential for economic development in Africa [1]. The current electrification figures show that countries in sub-Saharan Africa are facing major challenges in reaching positive economic growth and supplying basic energy services to rural communities [2]. Sustainable energy technologies are available and can be used to great effect in Africa to alleviate this problem [3]. Sustainable energy technologies can also contribute to job creation [4]. The implementation of renewable energy technologies in sub-Saharan Africa to date, however, has not always been successful due to both technical and non-technical factors [4-9]. Prior to this study a comprehensive framework of factors to select renewable energy technologies did not exist. The purpose of this research was to develop such a framework and to validate it by means of empirical analyses.

\section{Methodology}

A triangulation of methodologies was used to determine the framework of factors [10]. The analysis of the literature investigated renewable energy technologies and their application, the challenges in renewable energy technologies for implementation in Africa, and the selection methods in the fields of project, portfolio, programme and technology management. This was followed by a focus group [11, 12] with three experts,[13] in which thirty eight factors that need to be taken into account during the selection of renewable energy technologies in Africa were identified [13]. The factors identified by the focus group were confirmed and the eleven most applicable factors were selected through a two-round Delphi study [14-16]. Finally, case studies on the implementation of renewable energy technologies were undertaken in three countries $[17,18]$. These case studies confirmed the eleven factors identified during the Delphi study and identified a further two factors that were added to the framework [19]. 


\section{Results}

The final list of factors, factors identified during the focus group, the Delphi study definition of each factor as well as the important issues for each factor identified in the case studies, is shown in Table 1.

Table 1. Framework of thirteen final factors to consider for sustainable, renewable energy technology selection in Africa

\begin{tabular}{|c|c|c|c|}
\hline $\begin{array}{l}\text { Factor } \\
\text { description }\end{array}$ & $\begin{array}{l}\text { Focus group } \\
\text { identification }\end{array}$ & Delphi study definition & $\begin{array}{l}\text { Important issues for each factor from } \\
\text { case studies }\end{array}$ \\
\hline \multicolumn{4}{|l|}{ Technology factors } \\
\hline $\begin{array}{l}\text { Ease of } \\
\text { maintenance and } \\
\text { support over the } \\
\text { life cycle of the } \\
\text { technology }\end{array}$ & $\begin{array}{l}\text { Maintenance/ } \\
\text { support }\end{array}$ & $\begin{array}{l}\text { Security of supply is } \\
\text { enhanced. It also implies } \\
\text { that spares are affordable } \\
\text { and can be easily acquired. }\end{array}$ & $\begin{array}{l}\text { Quality of the installations, the } \\
\text { maintenance plans, the training of } \\
\text { technicians, maintenance training for } \\
\text { users, keeping maintenance simple and } \\
\text { adapting the technology to the specific } \\
\text { environment }\end{array}$ \\
\hline $\begin{array}{l}\text { Ease of transfer } \\
\text { of knowledge } \\
\text { and skills to } \\
\text { relevant people } \\
\text { in Africa }\end{array}$ & $\begin{array}{l}\text { Transfer of } \\
\text { knowledge and } \\
\text { skills }\end{array}$ & $\begin{array}{l}\text { Transfer of knowledge and } \\
\text { skills to the community } \\
\text { involved. Dedicated } \\
\text { personnel to run the facility } \\
\text { are required. }\end{array}$ & $\begin{array}{l}\text { Identification of stakeholders to train; } \\
\text { methods of skills transfer applicable to } \\
\text { the environment; quality of training; } \\
\text { and formalization of skills transfer. }\end{array}$ \\
\hline \multicolumn{4}{|l|}{$\begin{array}{l}\text { Site selection } \\
\text { factors }\end{array}$} \\
\hline $\begin{array}{l}\text { Local champion } \\
\text { to continue after } \\
\text { implementation }\end{array}$ & $\begin{array}{l}\text { Local hero - } \\
\text { champion to } \\
\text { continue after } \\
\text { implementation }\end{array}$ & $\begin{array}{l}\text { Facilitators of the } \\
\text { technology exist which will } \\
\text { ensure that the facility will } \\
\text { continue after } \\
\text { implementation. }\end{array}$ & $\begin{array}{l}\text { Local champions must be identified } \\
\text { during technology selection, their } \\
\text { responsibilities must be clearly defined } \\
\text { and they must be aware of the long } \\
\text { term implications of their role }\end{array}$ \\
\hline $\begin{array}{l}\text { Adoption by } \\
\text { community }\end{array}$ & $\begin{array}{l}\text { Passion/ } \\
\text { ownership/ buy- } \\
\text { in/ adoption by } \\
\text { community, } \\
\text { responsibility }\end{array}$ & $\begin{array}{l}\text { Community adopting the } \\
\text { technology, accepting } \\
\text { ownership, demonstrating } \\
\text { buy-in and taking } \\
\text { responsibility }\end{array}$ & $\begin{array}{l}\text { A determination must be done of the } \\
\text { capacity of the population to adopt the } \\
\text { new technology, the benefits of the new } \\
\text { technology must be determined and } \\
\text { communicated to the community and } \\
\text { that measures must be in place to } \\
\text { ensure client satisfaction }\end{array}$ \\
\hline $\begin{array}{l}\text { Suitable sites } \\
\text { ready for pilot } \\
\text { studies }\end{array}$ & $\begin{array}{l}\text { Pilot study site } \\
\text { selection issues }\end{array}$ & $\begin{array}{l}\text { Pilot studies are necessary } \\
\text { to demonstrate technology } \\
\text { to decision makers }\end{array}$ & $\begin{array}{l}\text { Selection of pilot sites is very important } \\
\text { and valuable; pilot sites must be } \\
\text { selected in such a way that they will be } \\
\text { accessible for demonstration purposes } \\
\text { to the community }\end{array}$ \\
\hline $\begin{array}{l}\text { Access to suitable } \\
\text { sites can be } \\
\text { secured }\end{array}$ & Not applicable & $\begin{array}{l}\text { Access for implementers to } \\
\text { sites where the technology } \\
\text { can be implemented must } \\
\text { be secured up front }\end{array}$ & $\begin{array}{l}\text { Determine priorities of population; set } \\
\text { implementation targets; identify site } \\
\text { criteria; and identify site }\end{array}$ \\
\hline \multicolumn{4}{|l|}{$\begin{array}{l}\text { Economic/ } \\
\text { financial factors }\end{array}$} \\
\hline $\begin{array}{l}\text { Economic } \\
\text { development }\end{array}$ & $\begin{array}{l}\text { Economic } \\
\text { development } \\
\text { (community } \\
\text { eventually able } \\
\text { to pay), } \\
\text { economic }\end{array}$ & $\begin{array}{l}\text { Economic development } \\
\text { translates into (a) the } \\
\text { community being able to } \\
\text { pay for services and (b) } \\
\text { economic sustainability }\end{array}$ & $\begin{array}{l}\text { Income generation, cost and time saving } \\
\text { and national income and savings all } \\
\text { contribute to economic development }\end{array}$ \\
\hline
\end{tabular}




\begin{tabular}{|c|c|c|c|}
\hline $\begin{array}{l}\text { Factor } \\
\text { description }\end{array}$ & $\begin{array}{l}\text { Focus group } \\
\text { identification }\end{array}$ & Delphi study definition & $\begin{array}{l}\text { Important issues for each factor from } \\
\text { case studies }\end{array}$ \\
\hline & sustainability & & \\
\hline $\begin{array}{l}\text { Availability of } \\
\text { finance }\end{array}$ & $\begin{array}{l}\text { Available } \\
\text { budget - the } \\
\text { finances to } \\
\text { support a } \\
\text { project }\end{array}$ & $\begin{array}{l}\text { The determination of the } \\
\text { required budget and the } \\
\text { availability of finance for } \\
\text { this budget are addressed } \\
\text { here. The type of finance } \\
\text { whether debt, equity or } \\
\text { grant must also be taken } \\
\text { into account. }\end{array}$ & $\begin{array}{l}\text { Finance can be facilitated by } \\
\text { implementing payment methods which } \\
\text { are applicable for the households, as for } \\
\text { example, bartering and that finance } \\
\text { methods must be in place before the } \\
\text { technology can be implemented on a } \\
\text { large scale }\end{array}$ \\
\hline
\end{tabular}

\section{Achievability by performing organization}

\section{Business} management

$\begin{aligned} & \text { Financial capacity } \text { Financial } \\ & \text { capacity }\end{aligned}$

Technological capacity

Proper project
management
The performing organization

having the business management capacity and procedures in place to ensure that the implementation of technology can be done successfully

Both the administrative capacity to manage finances and the ability to deliver, given the payment conditions.

The performing organization has the correct technology necessary for implementation of the project at their disposal.
Which business management skills should be transferred, how the skills are to be transferred and what to do in the short term when the skills of the organization are lacking

Financial capacity for performing organizations can be problematic at the outset but that various methods can be used to alleviate the financial capacity required by the performing organization.

Technological capacity is directly related to quality. Quality assurance must be enforced; regulation of performing organizations and the dictating of standards also contribute to quality installations.

\begin{tabular}{|c|c|c|c|}
\hline \multicolumn{4}{|l|}{ Other factors } \\
\hline $\begin{array}{l}\text { Government } \\
\text { support }\end{array}$ & $\begin{array}{l}\text { Regulatory } \\
\text { financial } \\
\text { incentive, tax } \\
\text { regimes must } \\
\text { be supportive" } \\
\text { and does it fit } \\
\text { under national } \\
\text { priorities }\end{array}$ & $\begin{array}{l}\text { Governmental support has } \\
\text { been obtained for the } \\
\text { technology }\end{array}$ & $\begin{array}{l}\text { In the first place, the government must } \\
\text { be aware of the new technology and } \\
\text { support its implementation. If the } \\
\text { government is also prepared to assist in } \\
\text { the implementation, success of } \\
\text { implementation is further enhanced. }\end{array}$ \\
\hline $\begin{array}{l}\text { Environmental } \\
\text { benefits }\end{array}$ & $\begin{array}{l}\text { Environmental } \\
\text { impact } \\
\text { assessment }\end{array}$ & $\begin{array}{l}\text { The implementation of the } \\
\text { technology will have a } \\
\text { positive impact on the } \\
\text { environment }\end{array}$ & $\begin{array}{l}\text { Environmental benefits may include: } \\
\text { decrease in the release of greenhouse } \\
\text { gasses; protection of fragile ecosystems; } \\
\text { halting soil erosion; halting } \\
\text { desertification; prevention of fresh } \\
\text { water pollution. }\end{array}$ \\
\hline
\end{tabular}

The focus group used the nominal group technique to identify 38 factors that need to be taken into account for the selection of renewable energy technologies in Africa and classified these factors into six categories. 
The Delphi study was conducted over two rounds with the purpose of confirming and prioritising the factors identified during the focus group. The Delphi questionnaires were sent to experts (both academics and practitioners) in the field of renewable energy, with the emphasis on Africa.

In the first round, respondents were presented with the factors identified during the focus group and then asked to: comment on the classification of factors; comment on the description of factors; provide additional factors that were overlooked during the focus group; and provide a preliminary rating of the factors identified during the focus group in terms of feasibility, desirability and importance of considering these factors during the selection of renewable energy technologies in Africa. At the end of the first round Delphi the factors were regrouped into four categories.

In the second round of the Delphi study, the respondents were presented with a summary of the comments and ratings supplied in the first round and were then asked to supply new ratings in terms of feasibility, desirability and importance. The results were analysed. Eleven of the factors were rated by the experts to be feasible, highly desirable and highly important when selecting renewable energy technologies in Africa.

The eleven factors identified in the Delphi study were then used to generate the framework for the eight case studies which were conducted in the following three African countries:

Rwanda; Tanzania and Malawi. The sources of evidence used included interviews, documentation and observation. The case studies confirmed that the eleven factors identified during the Delphi study are important for the selection of renewable energy technologies in Africa. Two additional factors were also found to be important and the wording of one of the factors was changed.

In conclusion, the thirteen most important factors that need to be considered for the selection of renewable energy technologies in Africa have been collated into a framework. 


\section{Discussion and/or Conclusions}

The critical documentation that must be generated before renewable energy technologies are selected in Africa is shown in Table 2 . The issues that have been identified in this study that must be addressed for each of the factors are also shown.

Table 2. Critical documentation for selection of renewable energy technologies in Africa

\begin{tabular}{|c|c|c|c|c|c|}
\hline Description & Quality plan & Maintenance plan & Technology plan & Human resource plan & Financing plan \\
\hline \multicolumn{6}{|l|}{ Technology factors } \\
\hline $\begin{array}{l}\text { Ease of } \\
\text { maintenance and } \\
\text { support over the } \\
\text { life cycle of the } \\
\text { technology }\end{array}$ & $\begin{array}{l}\text { Standards, monitoring, } \\
\text { evaluation, corrective } \\
\text { action, responsibility, } \\
\text { warranty }\end{array}$ & $\begin{array}{l}\text { Operator } \\
\text { maintenance, } \\
\text { technical } \\
\text { maintenance, } \\
\text { spares }\end{array}$ & Adaption of technology & Responsibility for maintenance & $\begin{array}{l}\text { Maintenance funding } \\
\text { model }\end{array}$ \\
\hline $\begin{array}{l}\text { Ease of transfer of } \\
\text { knowledge and } \\
\text { skills to relevant } \\
\text { people in Africa }\end{array}$ & & & & $\begin{array}{l}\text { Local skills levels, operator } \\
\text { training and manuals, technical } \\
\text { training and manuals, } \\
\text { responsibility, quality, } \\
\text { stakeholders, skills transfer }\end{array}$ & $\begin{array}{l}\text { Skills transfer funding } \\
\text { model }\end{array}$ \\
\hline \multicolumn{6}{|l|}{ Site selection factors } \\
\hline $\begin{array}{l}\text { Local champion to } \\
\text { continue after } \\
\text { implementation }\end{array}$ & & & & $\begin{array}{l}\text { Identification of local } \\
\text { champions }\end{array}$ & \\
\hline $\begin{array}{l}\text { Adoption by } \\
\text { community }\end{array}$ & & & $\begin{array}{l}\text { Capacity determination, benefits } \\
\text { determination, information } \\
\text { distribution, adoption probability }\end{array}$ & & \\
\hline $\begin{array}{l}\text { Suitable sites ready } \\
\text { for pilot studies }\end{array}$ & & & Selection of pilot sites & & Pilot site funding model \\
\hline $\begin{array}{l}\text { Access to suitable } \\
\text { sites can be } \\
\text { secured }\end{array}$ & & & $\begin{array}{l}\text { Priorities of population, } \\
\text { implementation targets, site } \\
\text { criteria identification }\end{array}$ & & \\
\hline \multicolumn{6}{|c|}{ Economic/ financial factors } \\
\hline $\begin{array}{l}\text { Economic } \\
\text { development }\end{array}$ & & & & & $\begin{array}{l}\text { Income generation, } \\
\text { domestic cost and time }\end{array}$ \\
\hline
\end{tabular}




\begin{tabular}{|c|c|c|c|c|c|}
\hline Description & Quality plan & Maintenance plan & Technology plan & Human resource plan & Financing plan \\
\hline & & & & & $\begin{array}{l}\text { savings, national income } \\
\text { saving }\end{array}$ \\
\hline $\begin{array}{l}\text { Availability of } \\
\text { finance }\end{array}$ & & & & & $\begin{array}{l}\text { Initial investment donor } \\
\text { funding, loan availability } \\
\text { and rates, government } \\
\text { support }\end{array}$ \\
\hline \multicolumn{6}{|c|}{ Achievability by performing organization } \\
\hline $\begin{array}{l}\text { Business } \\
\text { management }\end{array}$ & & & & $\begin{array}{l}\text { Capabilities of current } \\
\text { organizations, business skills } \\
\text { training, interim measures }\end{array}$ & \\
\hline Financial capacity & & & & $\begin{array}{l}\text { Administrative capacity of } \\
\text { performing organizations }\end{array}$ & $\begin{array}{l}\text { Capital outlay } \\
\text { requirements, capital } \\
\text { outlay funding }\end{array}$ \\
\hline $\begin{array}{l}\text { Technological } \\
\text { capacity }\end{array}$ & $\begin{array}{l}\text { Quality assurance } \\
\text { responsibility; technical } \\
\text { guarantees }\end{array}$ & After sales service & $\begin{array}{l}\text { Technological capacity of } \\
\text { performing organization, } \\
\text { regulation of standards for } \\
\text { technology }\end{array}$ & $\begin{array}{l}\text { Manufacturing training, } \\
\text { installation training, } \\
\text { maintenance training, refresher } \\
\text { courses, quality training, } \\
\text { technical backstopping }\end{array}$ & $\begin{array}{l}\text { Financial incentive for } \\
\text { quality }\end{array}$ \\
\hline \multicolumn{6}{|l|}{ Other factors } \\
\hline $\begin{array}{l}\text { Government } \\
\text { support }\end{array}$ & & & $\begin{array}{l}\text { Government acceptance and } \\
\text { support; energy policies, } \\
\text { legislation and standards }\end{array}$ & & $\begin{array}{l}\text { Relief on taxes or duties; } \\
\text { funding or subsidies; } \\
\text { licensing }\end{array}$ \\
\hline $\begin{array}{l}\text { Environmental } \\
\text { benefits }\end{array}$ & & & $\begin{array}{l}\text { Environmental benefits of } \\
\text { technology }\end{array}$ & & \\
\hline
\end{tabular}


The critical documentation can be used at various levels and by various organizations to select the most appropriate renewable energy technologies for implementation in Africa. The critical documentation must be completed for each competing technology. The technology that performs the best in terms of addressing all the issues for all of the factors can then be selected. By using the framework proposed in this study, selection of renewable energy technologies can be done with the assurance that the most important factors for the successful implementation of these technologies have been taken into account.

The successful implementation of renewable energy technologies in Africa will lead to the improvement of the lives of the population in Africa, will increase their productivity and quality of life, and will contribute towards the alleviation of poverty and the empowerment of women and children. African children who have sustainable access to energy will be better educated and thus be better future leaders.

Further work is required to implement the factors into a selection method for example the analytical hierarchy process or analytical network process.

\section{References}

[1] International energy agency, "Renewables in Global Energy Supply: An IEA Fact Sheet," vol. 2008, Not stated, 2007.

[2] Energy sector management assistance program, "Technical paper: energy sector reform and pattern of poor: Energy use and supply a four country study: Botswana, Ghana, Honduras and Senegal," vol. 2008, 2006.

[3] United Nations Energy Agency, "Energy for sustainable development: Policy options for Africa," vol. 2008, 2007.

[4] G. Prasad and E. Visagie, "Renewable energy technologies for poverty alleviation. Initial assessment report: South Africa," vol. 2007, 2005.

[5] I. Dunmade, "Indicators of sustainability: assessing the suitability of a foreign technology for a developing economy," Technology in Society, vol. 24, pp. 461-471, 2002.

[6] K. A. Ruder, M. W. Pretorius and B. T. Maharaj, "A technology selection framework for the telecommunications industry in developing countries," in ICC 2008 Proceedings, 2008, pp. 5490.

[7] S. Teitel, "On the concept of appropriate technology for less industrialised countries," Technological Forecasting and Social Change, vol. 11, pp. 349-369, 1978.

[8] O. J. Ebohon, B. G. Field and R. Ford, "Institutional deficiencies and capacity building constraints: the dilemma for environmentally sustainable development in Africa," International Journal of Sustainable Development \& World, vol. 4, pp. 204-213, 1997.

[9] B. T. Jimenez, A. Alvear, A. AlYabes and A. Olaoye, "Technology assessment and selection of renewable energy sources in the galapagos islands - ecuador," in PICMET 2007 Proceedings, 2007, pp. 2509.

[10] T. A. Scandura and E. A. Williams, "Research methodology in management: Current practices, trends and implications for future research," Academy of Management Journal, vol. 43, pp. 1248-1264, 2000.

[11] R. Blackburn, "Breaking down the barriers: Using focus groups to research small and medium-sized enterprises," International Small Business Journal, vol. 19, pp. 44-63, 2000. 
[12] A. Gibbs, "Focus Groups," Social Research Update, vol. 19, pp. 1-7, 1997.

[13] M. Barry, H. Steyn and A. C. Brent, "The use of the focus group technique in management research: the example of renewable energy technology selection in Africa," Journal of Contemporary Management, vol. 6, pp. 229-240, 2009.

[14] F. Hasson, S. Keeney and H. McKenna, "Research guidelines for the Delphi survey technique," Journal of Advanced Nursing, vol. 32, pp. 1008-1015, 2000.

[15] A. L. Delbecq, A. H. ven de Ven and D. H. Gustafson, Group Techniques for Program Planning: A Guide to Nominal Group and Delphi Processes. Glenview, IL: Scott, Foresman and Company, 1975.

[16] M. L. Barry, H. Steyn and A. C. Brent, "Determining the most important factors for sustainable energy technology selection in Africa," South African Journal of Industrial Engineering, vol. 20, pp. 33-51, Nov, 2009.

[17] M. Barry, A. C. Brent and H. Steyn, "Selection of renewable energy technologies in africa: The case of efficient stoves in malawi," in Second International Conference on Energy and Sustainability, 2009, 2009, .

[18] M. Barry, A. C. Brent and H. Steyn, "Selection of renewable energy technologies in africa: The case of bio-gas in rwanda," in $18^{\text {Th }}$ International Conference on the Management of Technology (IAMOT 2009), 2009, .

[19] M. Barry, "Contributions to the Theory and Practice of Technology Selection: The Case of Projects to Ensure a Sustainable Energy Base for Africa," 2010. 